\title{
Children as the Symptom Bearers: supporting South Asian Families through School Interventions
}

\author{
Jaswant Guzder (McGill University)
}

\begin{abstract}
This paper will focus on the interface of school, children, families and mental health support for South Asian immigrant children and adolescents in a Quebec context. South Asian students have often been considered a model minority with strong educational achievement. South Asian culture inherently has both protective factors and dissonances with mainstream culture, which often places a burden of cultural negotiation on children and youth. A few clinical vignettes will outline some of the complexities of the ethical, identity, social and mental health agendas that are vital to a discourse on the school as a factor in these negotiations of children and adolescents.

While the rates of self referral by South Asian families seeking child mental health services remain low, the school as well as social services are often the social institutions promoting mental health intervention. In this context, school staff and counselors may need to build on cultural competencies to deal with increasing culturally diverse school populations. In addition, current South Asian immigrant and refugee populations in schools may have significant pre-immigrant trauma whether from circumstances of poverty, social, domestic or war related causes as demographics of migration are changing. The social realities of Quebec (Bouchard G. et Taylor, C 2008) have also changed as the priorities of language assimilation are promoted to create a cohesive society while the social space seeks to balance an equitable place for minority cultures and influences. Schools are implicated in this socio-psychological dynamic of dealing with increasing immigrant populations from origins outside Europe or North America while they promote both academics and student resilience.
\end{abstract}

\begin{abstract}
Résumé
Cet article visera sur l'interface de l'appui scolaire, infantile, familial et santé mentale disponible pour les enfants et adolescents d'immigrants d'Asie du Sud, dans le contexte québécois. Les étudiants Sud-Asiatique sont souvent considérés comme un modèle de minorité ayant de forts résultats scolaires. La culture sud-asiatique possède et des facteurs conservateurs et des dissonances par rapport à la culture dominante, ce qui souvent pèse lourd sur les enfants et les jeunes dans leur négociation culturelle. Quelques vignettes cliniques souligneront quelques-unes des complexités des programmes d'éthique, d'identité, de société et de santé mentale, qui sont vitaux pour tout discours sur l'école comme facteur dans ces négociations d'enfants et d'adolescents.

Quoique le taux de familles sud-asiatiques ayant, d'eux-mêmes, recours aux services de santé mentale pour enfant, reste bas, l'école ainsi que les services sociaux sont souvent les institutions sociales qui encouragent les interventions en santé mentale. Dans ce contexte, le personnel scolaire et les conseillers devraient développer des compétences culturelles afin de gérer la croissante d'une population scolaire culturellement diversifiée. De plus, les actuels immigrants Sud-Asiatiques et la population de réfugiés peuvent très bien souffrir de significatifs traumatismes pré-migration, quelque soit les circonstances dues à la pauvreté, aux effets sociaux, domestiques ou liés à la guerre étant donné que les démographies migratoires changent. Les réalités sociales de Québec (Bouchard, G. et Taylor, C., 2008) changent aussi, autant que les priorités accordées à l'assimilation langagière sont promues afin de créer une société unie pendant que le milieu sociale cherche à équilibrer un espace équitable pour les cultures et les influences des minorités. Les écoles sont impliquées dans cette dynamique socio-psychologique qui gère un nombre croissant d'immigrants venant de pays autres que l'Europe et l'Amérique du Nord, tout en encourageant, et le travail scolaire, et l'ajustement personnel de l'élève.
\end{abstract}




\section{INTRODUCTION}

This paper will present some issues relevant to a mental health discourse on South Asian school aged children within the context of Quebec, and illustrated with some clinical vignettes of parent, child, school and mental health intervention. Though we have little specific research on the underlying causes, the low self-referral for mental health services from first generation South Asian families might suggest both positive functioning of most South Asian immigrant children and cultural parameters around help seeking for mental health services (Kirmayer, 2007).

Unlike the west coast of Canada which received South Asian migrants from the late 1800's, the history of Quebec's migration of the South Asian diaspora occurred in waves with a first significant rise around 1970's, while later waves of migrations included refugees from conflict regions in Bangladesh, Sri Lanka, India and Pakistan. While previous generations of migrants to the eastern part of Canada had been predominantly educated professionals, immigration demographics shifted to an increasingly heterogeneous migrant population from a wider spectrum of ethnic, socio-economic and educational backgrounds. It is likely that these child populations had a higher risk of traumatic experiences prior to migration (Rousseau and Guzder, 2008, Hyman, Beiser \& Vu, 1996), due to pre-immigration familial or political trauma. There is some concern that in the past five years more South Asian youth especially in the Canadian metropolis are experiencing increased stress related to reports of social identity dissonances, violence, drug abuse, academic and mental health problems (Wadhwani, 2002; Sharma et al. 2005; Tummala-Narra, 2007; Ghuman, 1994) within familial or extra-familial spaces. South Asian communities however continued to have very low rates of referral and self referral for additional support of institutional services (Messent and Murell, 2003) in education or mental health settings.

\section{DIVERSITY AND MENTAL HEALTH}

As a child psychiatric consultant working in a hospital setting, the South Asian patients I have encountered have largely been referred by their parents at the urging of social service agencies or concerned schools. For a variety of reasons including stigma and cultural frames of reference, South Asian families often would not consider using mental health services proactively, though amongst increasingly mobile, urban and educated South Asian generations there is increasing openness to seeking these services. Spirituality, extended familial supports and alternative mental health strategies are often frames of wellness that may co-exist within South Asian diaspora families along with mainstream mental health options. South Asian children have indeed been often been described as 
the model visible migrant population (obedient, high achievement, socially adaptive). However each visible minority group or community is heterogeneous and may have unique socio-historical roots that significantly impact the child's identity, strengths and resiliency in post migration adjustment.f Diversity of dress, language and identification with cultural signifiers were raised within the recent public provincial forums of the Bouchard-Taylor Commission hearings (Bouchard, G. et Taylor, C. 2008 ) who underlined the pressing need to balance protection of the dominant Quebecois cultural values along with finding an equitable place for minority and emergent migrant agendas. While South Asian issues have remained relatively 'under the radar', there have been considerable concerns in Quebec society about bicultural issues such as dress codes, religious symbols and forced marriage. Such cultural dilemmas were reflected in the publicity around the subgroup of orthodox Sikh children who carry kirpans (a traditional dagger, which is a religious symbol ) in public schools in Quebec and issues related to the hijab ( headscarf) amongst Islamic girls The kirpan issue in Quebec had become a heated social and legal debate in 2006, later resulting in the Supreme Court ruling to allow kirpans in schools in recognition of its religious symbolism. There was a societal discourse on protecting the rights to religious identity above the school's concern around safety (ie. the carrying of weapons in public schools). The carrying of a kirpan by some Sikhs and wearing of headscarf by some Muslim students were resurrected in public discourse several times in relation to recent school incidents. Schools ( Rousseau et Guzder 2008, Szente, 2006) struggle with these cultural, ethical and politicized issues as dynamic settings within the social space where assimilation and adaptation are active processes. The prevailing Quebec school initiatives and policies remain supportive of rapid integration, giving migrant children the tools to quickly enter mainstream French Canadian culture.

These assimilation promoting policies largely avoid discussion on institutional attitudes that challenge homogeneity, uncover intercultural strain (Hall 2001; Akhtar, 1999) or suggest the need to provide teachers with wider skills in cultural competence. The majority of South Asian children, whose colonized origins gave many of them English language skills, enter French public schools under the Bill 101, which applies to all migrants by "welcoming" these children into classes d'accueil settings. These 'welcome classes' deal with children who have no French skills and are aimed at supporting fluency and positive social adjustment in a francophone cultural space. Language supports assimilation and positions social and linguistic post-migratory adjustment. At times, the language of school may also become a barrier to communication, treatment and integration for those parents or children of South Asian origin who 
have not achieved full French language mastery. While there are universal and culturally specific resistances which can be impediments to parental involvement with schools, language can be considered as a unique predicament to furthering school based mental health services in Quebec, as reflected in some of the case examples.

In terms of the translation of strengths and vulnerabilities, South Asian child populations would have the benefit of identifying with the host society as well as having the implicit influences of their countries of origin cultures (Kleinman, 1980). This psychological bicultural space is indeed an additional psychological burden for bicultural children as it is negotiated in the realm of multiple psychological, external, implicit, familial, gender and sociopolitical influences. The individual narratives or variations in hybrid or creolized identity that emerges from this flux of issues are heterogeneous and complex (Akhtar,1998). Bicultural nuances, strengths and vulnerabilities provide both resiliencies as well as challenges. Studies of traditional South Asian societies confirming very low rates of mental disorder (Pillai et al., 2008) support the concept of cultural protective factors. Studies of South Asian immigrant children moving to the United Kingdom (Goodman et al. 2008) however suggested rates of mental disorder may approximate host country rates, raising concerns that immigrant South Asian children, particularly Bangladeshi and Pakistani children, were possibly underserviced in these child populations.

The familial and intra-generational worlds of South Asian children who have strong connections with their country of origin or communities will be different from those who are relatively isolated from their cultural roots. Many studies in Euro-North American settings have underlined that some South Asians groups adapt well in North America but do not necessarily integrate (Stopes-Roe, 1987) or may assimilate progressively over generations. Though second generation children (Singla, 2009; Levitt, 2002) may remain attached more to the country of residence rather than country of origin of their parental generations, first and third generations will have different attachment relationships to the subcontinent culture. Such attachments or assimilations evolve over time (Akhtar, 1999) and are often influenced by school or social environments shaping identity as well external realities such as religious and socio-political dimensions encouraging or resisting acculturation shifts. The particular vulnerability of Islamic communities in the post $9 / 11$ context emerged as such a predicament in North America. 


\section{CLINICAL VIGNETTES}

The clinical vignettes of children presented here underline some bicultural challenges with social, ethical and mental health aspects These vignettes will underline the need for building school and mental health alliances that might bridge institutional discourses with parents and children. Including a cultural axis (American Psychiatric Association, 2009) or cultural formulation as part of our thinking will support a widening of the reflective space as we make our way through the issues of school support. Questioning our ethnocentric or Euro-North American value systems, which are not universally accepted by migrant families, might well further our empathy and expand our ethical considerations for intervention aims.

\section{P.: the invisible child}

P., an 8 year old child, was referred by his social worker for a consultation as she was concerned about his withdrawal symptoms and possible depression. He had been born in Quebec, spent his early development on the Indian subcontinent and attended Quebec French schools from his primary level. His single mother, who suffered from a debilitating schizophrenia, was often non-compliant for medication, and had been abandoned by P's father during the pregnancy. She had no network amongst the South Asian community as her behaviour was bizarre and increasingly isolated her and her son. The original referring social worker had assisted in arranging his mother's multiple hospitalizations. At times, the child's maternal grandparents had been involved and indeed, they had raised him in India most of his infancy to preschool life as his mother was too ill to care for him.

After P.'s traumatic reunion with his mother at age 4 when he was brought back from India, his grandparents would visit him irregularly if his mother was profoundly ill. They would reinforce that he was his mother's guardian and validate his parental role with regular supportive phone calls. They conveyed to him a religious and spiritual framework reinforcing that his mother's schizophrenia related to karmic influences (past life retributions) and asked him to perform regular pujas (prayer and rituals) to reverse her suffering. Within this religious framework, he felt safe, as this framework also reinforced an attachment to his loving grandparents. At the same time that his mother's psychosis left him bewildered with pain and helplessness as a parental child, he also felt empowered to help his mother in efforts to reverse her illness with his efforts of prayer. For many years, he was unable to reconcile the "western" view of schizophrenia as a biological genetic illness. In addition, his maternal 
grandparents' spiritual-religious construction, had also provided a protective defense against his great fear of becoming psychotic himself.

Though we worked together beyond his adolescence, he was not able to reveal until his late twenties, how the anguish of his inner loyalty to his grandparents' view of his mother's disorder and the information from me suggesting that schizophrenia was a biological illness, had created an internal schism. The bicultural negotiations were processed over many years and he had to internally construct a bridging of the two worldviews without losing the positives from either cultural space.

He psychologically survived by developing a warm social link with a peer group at school, which fostered his resilience and remained an alternate present family replacing his far away extended Indian family. He continued to do well in his studies and sports despite his chaotic and unpredictable life at home, though he was often depressed or very angry at his overwhelming situation. Several times, I called his schools (elementary and high school) to request additional supports and was told that he was not a behaviour problem and they stated they had no request from his mother. As they had only unilingual francophone staff and did not use interpreters, their attitude appeared to be one of benign neglect towards a non- francophone parent who never called or interacted with them. They considered my calls intrusive (undermining the parent's right and child's individual rights to seek help as needed unless it was a youth protection mandate). They stated they did not feel equipped to respond to my consultations, nor did they welcome a cultural explanation of his stress. I raised concerns that the mother did not speak French, and South Asian cultural boundaries tend to reinforce intra-familial privacy as well as reinforce the shame and stigma of sharing mental health difficulties outside of the family.

Despite difficult times of stress, P. graduated from high school supported by his grandparents in India, social workers in the community, peer supports and therapy sessions. He felt very vulnerable to shame within the school system ("they will never understand me") and did not want to come to their attention fearing he would be placed away from his mother. He stated that his invisibility was both a blessing (fear of school misunderstanding or forcing placement) and an abandonment ("they don't want to know me"). The school invested no interest in his family predicament and I failed to engage them in building any bridges.

\section{Ayesha: a marriage arranged before graduation}

Ayesha, a seventeen year old South Asian girl, was seen in consultation with her high school counselor who was very concerned about her "forced marriage" on graduation. The counselor sought a cultural consultation. The girl agreed 
provided her parents did not know about her mental health consultation. Her confidentiality was protected as an adolescent above age fourteen in Quebec.

Ayesha was an excellent student and had planned to proceed to university when her family announced plans for her marriage on graduation. When she was fourteen years old, her family had reunited with her father who had migrated to Quebec many years before in her early childhood. She idealized her father who had encouraged her in her studies. She also had a warm relationship with her extended family in her country of origin. However she had always had a highly conflicted relationship with her mother who had always been somewhat cold to her and warmer towards her brothers.

Her mother became increasingly depressed, as well as increasingly critical and somewhat abusive towards Ayesha in this post-migration period while Ayesha had a parental attitude towards her mother. Ayesha felt emotionally abused by her mother but explained her mother's behaviour as her displaced irritation and distress related to earlier losses. She recognized that her mother might have envied her new possibilities as a good student. She felt that her mother had been an entitled younger daughter in her family of origin and, for her, migration had meant a downward migration with loss of servants, a large family home, extended family support in a familiar South Asian context, and she was now experiencing a difficult and isolated life in the "deep freeze of Canada". Ayesha felt her father's affection for her was difficult for her mother to tolerate, as she was missing the warmth of her family and felt her husband was not demonstrative.

Her counselor had been very willing to be a confidant to Ayesha but had sought a consultation as the cultural issues seemed "far out of my Canadian experience." In addition, he noted that the family did not volunteer any concerns and only the father dealt with the school. The girl had been adamant that her situation at home would be much worse if he broke her confidence or let her family know that these issues filled her with anguish. She was especially concerned that they must not know that she had sought help outside the family. The counselor had suggested that the mother could be signaled to youth protection for abusing the girl and offered to have her placed outside the home particularly as honour killings had been raised in recent news stories. She was horrified at this suggestion and told him that she would "lose her family forever" if he betrayed her confidence. She had wanted him to continue to provide support and validation, "a safe place" to explore her internal issues. She was grateful to the counselor to providing information to promote her adjustment and studies. She was fully aware that moving out of the home was an option, though she considered this as only one approach to her problem. She had not wanted 
such an early marriage but more importantly, Ayesha wanted to marry someone who would allow her to be educated and to work after marriage. The counselor and I had first met to discuss this issue and we had discussed her culturally syntonic option of arranged marriage and issues important to Ayesha's, identity as she had been raised largely in South Asia.

When we met with Ayesha she was very articulate. She was able to explore her conflicts, needs and hurts. She felt her mother's anger would not diminish and that an early marriage was a solution to her family conflicts where she was being treated "like a servant." While she regretted that she was often the object of her mother's envy or displaced anger, she felt sympathetic towards her mother. She was clear that the solution she preferred was to work with extended family in her country of origin to find a partner who would respect her need to be educated. She understood the negotiation of the marital choice could be influenced by senior aunts and uncles in the family who could override her mother's initial choice of a cousin marriage. She begged the counselor to trust her decision and felt relieved that she was understood in our joint session. On follow-up years later, Ayesha had indeed been happily married. Her elders had acknowledged her need for education and career in arranging her marriage. She remained grateful to the counselor for his restrained, trusting approach to her predicament and for providing a safe place for bicultural reflection. The school had a large migrant population and had many efforts to seek bridges with the local minority communities.

\section{Salman: a boy who had difficulty learning}

A Bangladeshi Muslim family requested a psychological assessment as they had heard our clinic was welcoming to migrant families. Their 9 year old son Salman had been in a classe d'accueil since age 6, and had not progressed to regular classes as he had not mastered French, nor had he been assessed for learning problems despite their requests. The couple had moved from Bangladesh to the west coast of Canada where Salman was born, but later moved to the United States where he had been in English schooling from age 4. He had been assessed for severe developmental delays in expressive and receptive language prior to leaving Canada at age 4 and then fully assessed again in the United States. The couple were unable to have more children as the mother was older and she had become very depressed dealing both with her concerns about her son, her miscarriages and marital tensions. The father felt ashamed and distressed that his protective efforts to shelter his family and get services for his son had failed in the past few years. The couple had interpreted the school's resistance to testing 
their son or helping him get adequate services as a form of post 9/11 institutional racism which only added to their distress.

We consulted the school that explained initially that they felt the child was doing well in French and did not require assessment. We discussed the fact that the child did not have good expressive skills in his maternal language Bengali nor was he able to communicate in French in our sessions. We discussed the well documented past history of speech disorder assessments which they had in their files. They explained that were very reluctant to proceed with testing for classe d'accueil children who had alternate languages at home as they felt these children required 'more time' to master French and an assessment might be "unfair". We were able to provide some new testing at our clinic that validated the previous disorders in language but were still unable to motivate the school to consider options. The school remained reluctant to consider the child for eligibility for English schooling where he had done better pre-migration and the father who was the primary parent interacting with the school, felt completely obstructed.

During this process of consultation, the family continued therapy and became less conflicted internally. The parents were able to improve their team efforts to advocate for the child. They were successful in mounting their own public and school advocacy efforts with support. The couple also began to both grieve and accept their child's disabilities, enabling them to work through several impediments to supporting the child who had been overindulged prior to his finding a more appropriate school placement. He was doing well in follow-up five years later. The school has not given us feedback on this advocacy but made some effort to provide parents with feedback in English subsequent to the intervention by arranging for a bilingual staff member to deal with South Asian families rather than insisting on an interface with unilingual school staff. They also later supported the child's eligibility for transfer to English schooling.

\section{L.: a child who was drunk at school}

L. was adolescent Muslim boy who was seen in consultation after his placement. He had been seen by a school counselor for some months, complaining that his parents were very oppressive. His counselor had tried to be supportive and console him as the child continued to report that his parents were very strict and overly traditional, limiting his freedom in comparison to his Quebecois peer group. On one occasion he came to school drunk, which subsequently led to the school sending him home with a note. When he reluctantly revealed this incident to his parents, they were very upset by his conduct. L. had always been well behaved and a good role model to his younger sibling, and was aware that they 
had forbidden drinking for religious reasons. His parents had always been quite indulgent, never used physical punishments and seldom reprimanded him. On this occasion they both slapped him for his insolent attitude as he was unrepentant and defiant. His normally gentle mother had tapped him with her slipper on his head. L. took this incident to his school counselor the following day. As a result, the school informed youth protection and arranged immediate foster placement, L. was taken from the school without contacting the parents.

During the sessions with the family and L. that followed, his parents felt wounded that the authorities had believed their son without checking with them as they saw the school as taking the side of the child believing that they were oppressive parents. L. had indeed been asking for a cell phone and longer curfews as requests to his parents that would make him more like his Quebecois peer group. They had also not recognized the extent of his resentment of their ethnocentric religious values and his negative experience of being Muslim in his school environment. He had tried hard not to openly defy them when he was younger as well as trying to set a good role model for his younger sibling. He was pleased his mother had gone for French lessons and was now training for a job outside the home. L. was close this mother who initially felt guilty about her new initiative to attend classes, which had been a contributing factor to L.'s choices. Both of his parents felt that L. had much more autonomy than they had had growing up and had expected him to be obedient. They had wanted to transmit traditional family values and had hoped that L. would appreciate all the family sacrifices that had been part of their migration journey. His father had a business close to their home and had been aware of drug dealing as well as other transgressive activities of the neighborhood youth. He had wanted to protect $\mathrm{L}$. from these influences and explained to his son why he had resisted the idea of a cell phone.

L. refused to leave the placement until he negotiated more autonomy with his parents and the cell phone from his parents. After a consultation process, his social worker began to appreciate the acculturation agendas behind L.'s acting out (drinking before going to school) and his resistances to close supervision (curfews) as well as his family's value system. There was an appreciation that the single incident did not translate to impaired parental capacity or abuse potential. We were able to contract with L. what was expected of him as part of his behavioural responsibilities before returning home by which he could earn more autonomy.

His school counselor appreciated that he had a singular lens to view L.'s parents and that he had had little idea of the parental agendas or the bicultural strain. The episode left the parents very anguished and they felt that this response 
by the authorities was counter to all of their traditional understanding of working with hierarchies or cultural spaces. The role of youth protection in L.'s thinking was influenced by his understanding of the legal rights of children which was entirely different from the parental expectations of working with school authorities in their home country. While the school appreciated that the response had been very intrusive they felt they had made a good decision and implicated the youth protection services in the final decisions made for the safety of the children.

\section{K.: a child with anorexia}

K., an eight year old South Asian boy, was academically doing well in school when I first met him at the request of the school social worker. She was concerned as he was increasingly sad, withdrawn and had begun to lose weight, refusing to eat at school. He had been in Quebec since the age of three as a refugee claimant along with his single mother and when he was eight his family faced deportation orders. His mother had left a violent and abusive situation in her homeland. She was terrified of being returned and had often threatened suicide or even killing her children rather than face deportation. K. had become a parental child who was her "good boy", on the surface overly compliant and silent. He protested the unfairness of the deportation as he felt that Quebec was his only home "I am two hundred percent a Quebecer." His anorexia was both a silent protest to dealing with the agitated depression of his mother and the anguish of facing the loss of his home. His mother denied the issues of his pain and distress as she was already overwhelmed with avoiding deportation. K. had a supportive school social worker who had engaged him in sports and arranged for camp in summer. His symptoms diminished and he was able to remain a good student for the rest of elementary school. The school was exceptionally supportive and able to provide a caring therapeutic environment while his mother was preoccupied and depressed.

Eventually, his family was able to achieve a humanitarian appeal and attained immigrant status as he entered adolescence. Though his mother's functioning improved, the financial plight of the family remained fragile. He felt deprived of the life his peer group took for granted and his hunger for a father remained an underlying issue. In high school, he had no male mentors and he had become increasingly defiant about rules, estranged from authority, precociously autonomous and soon very "street smart." His school social worker again brought him for consultation and this time he openly spoke about his distress at being irrelevant to his country of origin and enduring years of precarious existence as a refugee. His mother had become very indulgent with $\mathrm{K}$. and she was reluctant to 
set curfews or limits yet understood he was at high risk. She felt more guilt ridden as her depression diminished and she was more afraid of losing his affection as he grew older. His unknown father's history as an abuser remained a barely conscious issue and he felt marginalized in both the host and ethnic communities. He sought some kind of potency, validation and belonging in a gang who then became a frightening problem in his daily life. He began to miss school to avoid gang encounters and was involved in various delinquent activities until his mother turned to social services in the school for help.

$\mathrm{K}$. was expelled from two schools and eventually his mother sent him back to South Asian extended family to see if he could be sheltered in her family of origin. The high school setting was unable to provide the sheltering support or engagement that could contain K.'s distress and acting out. Nonetheless, there was significant support by the social workers to provide a systemically informed intervention for his family and to support him in this distressing process before and on return from his family of origin visit. The therapeutic efforts of the resource team made use of culturally informed interventions and used translators with his mother to maximize her capacity to share and understand the issues of K.. When she brought him back from time with her family, he had a more balanced positive view of his origin culture and his mother's trauma. He was more willing to work with her and the social services to negotiate a structure and return to school though there were some ongoing concerns. A culturally informed consultation was helpful in formulating a treatment plan and bridged the various partners involved with the family and school.

\section{SUMMARY}

The roles of schools, mental health and social services are an important area for service response to distressed students. Support of South Asian children and families is primarily school based as they seldom seek mental health services. Schools are involved in recognition of needs while being the best place for preventive, proactive work and cultural translation. The cultural axis (American Psychiatric Association, 2000) is a useful addition to mental health understanding the underpinnings of behaviour problems, school failure or student distress. Sexuality, identity, academic performance, abuse, trauma and mental disorders are areas that may result as aspects of child problems across cultures (TummalaNarra 2007; Akhtar, 1999). Providing best practices for counseling includes addressing impediments to care and understanding that include a universal and specific approach while acknowledging that cultural threads should not be assumed or generalized to stereotypic motifs. Each child in the five clinical cases, given as examples, had widely different developmental, constitutional, familial 
and personal histories. School counselors and teachers form the first line of mental health care and need tools to empower and support them in this challenging endeavor. The training of teachers seldom involves supplying cultural competency skills or offering ongoing peer development as part of their training support. Creative workshops for expression in school based programs have been helpful in "holding" child narratives in some school initiatives (Rousseau et al. 2004; Rousseau and Guzder, 2008 ) and are one aspect of such skills.

The South Asian families usually have strong structure and hierarchy, but more importantly they have wide differences in migration histories, cultural assimilation and trauma experiences. The stigma around mental health issues is common in many developing countries where psychosis or severe disorders are diagnosed rather than acknowledging development obstacles, trauma, adjustment problems, identity disturbances, substance abuse or learning disabilities as having wide relevance to evolving children and adolescents. In addition, as migrant families are making these transnational (Singla, 2009) leaps, the cultural bridges involving such issues as language involves an influence on the host cultural space. In areas where there are high migrant school populations, the presence or absence of staff from minority communities in schools or agencies is an important additional aide to building bridges and alliances. Often South Asian fathers are the interactive parental figures with schools and family issues may be relatively invisible. The available resources of schools and the laws in Canada for child protection are often unclear to cultural communities but more apparent to their children so that psycho-education and communication with parents become even more important. As the host culture language can be a barrier to communication, bicultural children often act as the "go betweens", because they are expected to transmit school information to their parents. Otherness (Hall, 2001; Levitt, 2006) presents a challenge for schools who underestimate integration challenges, while maintaining their primary mandate of education. Collaboration of community partners, families and professionals can be helpful in understanding the needs and clarifying worthwhile support for the children of different cultural communities.

\section{References}

Akhtar, S..Kramer, S.(1998). The Colours of Childhood: separation-individuation across cultural, racial and ethnic differences. Northvale, New Jersey: Jason Aronson Inc.

Akhtar, S. (1999). Immigration and identity: Turmoil, treatment and transformation. Northvale, New Jersey: Jason Aronson Inc.

American Psychiatric Association (2000). Diagnostic and Statistical Manual for Mental Disorders (4 $^{\text {th }}$ ed.).Washington, DC : American Psychiatric Association Press. 
Bouchard,G., \& Taylor, C. (2008) Building the Future. Time for Reconciliation. Dialogue makes a difference. Commission de Consultation Sur Les Practiques D'Accommodation Reliées Aux Différences Culturelles. Biblioteque et Archives Nationales du Quebec.

Ghuman, P.A. (1994). Canadians or Indo -Canadians: a study of South Asian Adolescents. International Journal of Adolescence and Youth, 4, 229-243.

Goodman,A.,Patel,V., Leon,D.,(2008).Child Mental Health differences amongst ethnic groups in Britain: a systematic review. BMC Public Health. 8:258.

Hyman,I.,Beiser,M. \&Vu,N. (1996). The Mental Health of Refugee Children in Canada. Refuge. 15(5)4-8.

Worthman, C.M., Plotsky, P.M., Schechter, D.S., \& Cummings, C.C., (Eds.). (2010). Formative Experiences: The Interaction of Caregiving, Culture, and Developmental Psychobiology. Cambridge, MA: Cambridge University Press.

Kirmayer,L.J., Weinfeld,M., Burgos,G., du Fort,G.G., Lasry,J.C.,\&Young,A. (2007). Use of Health Care Services for Psychological Distress by Immigrants in an Urban Multicultural Milieu. The Canadian Journal of Psychiatry. 52(5)295-304.

Kleinman, A. (1980). Patients and Healers in the context of Culture: an exploration of the borderline between anthropology, medicine, and psychiatry. Berkeley: University of California Press.

Levitt, P., \& Waters, M. (Eds.). (2002). The Changing face of Home: Transnational Lives of Second Generation. New York: Russell Sage Foundation.

Messent, P., \& Murrell, M. (2003). Research Leading to Action: A study of Accessibility of a CAMH Service to Ethnic Minority Families. Child and Adolescent Mental Health, 8 (3), 118-124.

Pillai, A., Patel,V.,Cardoza,P.,Goodman,R., Weiss,H., Andrew,G. (2008).Non-Traditional Lifestyles and the Prevalence of Mental Disorders in adolescents in Goa,India. British J. of Psychiatry.192:45-51.

Rousseau, C., Singh, A., Lacroix, L., Bagilishya, D., \& Measham, T. (2004). Creative expression workshops for immigrant and refugee children. Journal of the American Academy of Child and Adolescent Psychiatry, 43(2), 235-238.

Rousseau, C., \& Guzder, J. (2008). School based Prevention Programs for Refugee Children. Child and Adolescent Psychiatric Clinics of North America, 17(3), 533-549.

Szente, J., Hoot,J., \& Taylor, D. (2006). Responding to the special needs of refugee children: practical ideas of teachers. Early Childhood Education Journal, 34(1), 15-20.

Sharma, P., Pisharodi, L., Moore. L., \& Weiser, J. (2005). Crossing the great Divide: Understanding the mental health needs of south Asian youth. Report prepared by East Metro Youth Services, commissioned by the Ministry of Children and Youth Services. Retrieved October 2006 from http://www.emys.on.ca/media/pdf/Crossing_the\%20Great_Divide.pdf

Singla, R., Fabricius, A., \& Holm, A. (2009). South Asian Diasporic Youth in Denmark: socio-economic strategies. Finnish Journal of Ethnicity and Migration, 4(1), 16-27.

Stopes-Roe, M., \& Cochrane, R. (1987). The process of assimilation in Asians in Britain: a study of Hindu, Muslim and Sikh Immigrants and their young adult children. International Journal of Comparative Sociology, 28, 43-56.

Jaswant Guzder, is Head of Psychiatry in the Center for Child Development and Mental Health Institute of Community and Family Psychiatry of McGill University; she can be contacted at jaswant@videotron.ca. 